\title{
Non-surgical treatment of large periapical lesions
}

\author{
Kyoung-Hwa Jung ${ }^{1,2}$, Eun-Young Kwon ${ }^{1}$, So-Yeun Kim ${ }^{1}$, Hye-Mi Jeon ${ }^{1}$, Youn-Kyung Choi ${ }^{1}$, Sung-Ae Son ${ }^{2}$, Jeong-Kil Park*
}

${ }^{1}$ Dental Clinic Center, Pusan National University Hospital, Busan, Korea

${ }^{2}$ Department of Conservative Dentistry, School of Dentistry, Pusan National University, Yangsan, Korea

Most periapical lesions can be classified as apical periodontitis, radicular cyst, or abscess. Treatment options for large periapical lesions management range from conventional endodontic treatment to surgical treatment and extraction. Recently, the surgical treatment is only administered if the conventional endodontic therapy fails to restore the integrity of the peripheral tissue. This case report submits the successful treatment of a large periapical lesion using non-surgical endodontic therapy.

Key Words: Conservative treatment, Periapical diseases, Periapical periodontitis, Radicular cyst

@ This is an open-access article distributed under the terms of the Creative Commons Attribution Non-Commercial License (http://creativecommons.org/licenses/by-nc/4.0) which permits unrestricted noncommercial use, distribution, and reproduction in any medium, provided the original work is properly cited.

\section{서 론}

치근단 병소(periapical lesions)는 치아 우식이나 외상에 의 해 감염된 치근단 치수와 치주인대 사이 계면에서 미생물에 대 한 숙주 반응으로 나타나는 근관계 감염의 결과물로, 이 반응을 통해 치근단 부위에 국소적 염증, 경조직의 흡수, 치근단 조직의 파괴 등이 발생하게 된다[1,2].

치근단 병소의 대부분( $90 \%$ 이상)은 치근낭(radicular cyst), 치근단 치주염(apical periodontitis), 농양(abscess)으로 분류 된다. 치근낭은 상피로 이장된 액체와 세포 잔사를 포함하는 공 동(cavity)을 섬유결합조직이 둘러싸는 형태로 조직학적 특성에 따라 크게 두 가지로 분류되는데, 공동 전체에 걸쳐 완전한 상피 이장을 보이는 경우를 진성낭(true cyst), 공동이 치근첨과 근접 하여 상피 이장이 근관으로 개통된 경우를 가성낭(bay-cyst)이 라고 분류한다[3,4].

커다란 치근단 병소(large periapical lesions)의 치료 방법 은 전통적인 비외과적 근관치료 방법부터 외과적 수술, 발치
까지 다양하다[5]. 병소의 크기가 너무 큰 경우나 진성낭 증례 의 경우 근관치료만으로는 효과적이지 않을 수 있어 감압술 (decompression), 조대술(marsupialization), 낭적출술(cyst enucleation)과 같은 외과적 접근법이 필요하기도 하다는 보고 가 있었으며[6], 1960년대까지 근관치료학자, 병리학자, 구강악 안면외과학자들은 근관치료로는 치근낭을 치료할 수 없다고 생 각하여 외과적 접근법을 사용해오기도 했다[7]. 하지만, 치근단 병소의 감별 진단은 조직학적 검사만으로 가능하며, 일반적으 로 치근낭과 치근단 치주염을 방사선사진만으로 구분하기는 어 렵다[8]. 따라서, 커다란 치근단 병소를 치료해야 하는 치과의사 들에게 적절한 치료 방법을 선택하는 것은 어려운 문제가 될 수 있다.

최근에 커다란 치근단 병소를 치료하는 추세는 비외과적 근 관치료를 우선적으로 시행하는 것이다. 대부분의 근관치료학자 들은 비외과적 접근법으로도 많은 치근낭들이 성공적으로 치료 될 수 있다고 하였으며, 치근단 병소를 가진 치아에 대해 근관치 료를 시행한 경우 94.4\%에서 완전한 또는 부분적 치유가 일어

Received April 5, 2019; Revised May 23, 2019; Accepted June 10, 2019

Corresponding author: Jeong-Kil Park, Department of Conservative Dentistry, School of Dentistry, Pusan National University, 20 Geumo-ro, Mulgeum-eup, Yangsan 50612, Korea.

Tel: +82-55-360-5221, Fax: +82-55-360-5214, E-mail: jeongkil@pusan.ac.kr

Copyright @ 2019, Oral Biology Research Institute 
났다는 보고가 있다[9-11]. 따라서, 이번 논문에서는 치아의 치 근단 조직에 발생한 커다란 치근단 병소를 비외과적 근관치료 방법을 통해 치료하였고, 성공적인 결과를 얻었기에 이를 보고 하는 바이다.

\section{증례보고}

\section{증례 1}

34세 남자 환자가 상악 좌측 전치부 순측 치은 부종 및 불편 감을 주소로 이전 치과에서 외과적 수술을 권유받고 구강악안 면외과에 내원하였고, 수술 시행 전 근관치료를 위해 치과보존 과로 의뢰되었다. 임상검사 및 방사선검사상 상악좌측측절치 (\#22)의 근심면에 치수와 인접하고 있는 수복물이 존재하였고, 치관 변색이 확인되었다. 상악 좌측 순측 전정에 부종이 관찰되 었으며 촉진 시 동통을 호소하였다. 방사선 사진상 \#22 치근단 부위부터 \#23 치근첨 부위에 걸친 커다란 치근단 병소가 관찰 되었으며, 컴퓨터 단층촬영(computed tomography, CT) 검사 결과 상악 좌측 순측 피질골이 얇게 남아있는 것을 확인할 수 있 었다(Fig. 1). 전기치수반응 검사 결과 \#22는 음성, \#23은 양성 반응을 보였다. 환자에게 이 병소를 치료할 수 있는 방법에 대 해 설명하였고 환자와 상의 후 먼저 비외과적인 근관치료를 시 행한 후 치료에 실패할 경우 수술적인 치료를 시행하기로 하고 \#22의 근관치료부터 시행하기로 하였다.

\#22의 구개면에 근관와동을 형성한 후 러버댐을 적용하 고 \#10 K-file과 근관장 측정기를 이용하여 근관장을 측정 (24 mm)하였다. 측정한 근관장에 맞춰 ProTaper Universal (Dentsply Maillefer, Ballagiues, Switzerland) S1, S2, F1 파일, ProFile (Dentsply Maillefer) .06/\#30 파일을 이용하여 순차적 으로 근관성형을 하였고, 각 파일의 사용 단계마다 $10 \mathrm{~mL}$ 이상
의 $2.5 \%$ 차아염소산 나트륨(sodium hypochlorite, $\mathrm{NaOCl}$ )을 이용하여 충분한 근관세척을 시행하였다. 그 후 근관을 페이퍼 포인트를 이용하여 건조시키고 근관 내는 수산화칼슘(calcium hydroxide)제재 근관첩약제인 Calcipex II (Nippon Shika Yakuhin Co., Ltd., Yamaguchi, Japan)를 적용한 후에 소독된 면구 및 임시 가봉재를 이용하여 근관와동 입구를 봉쇄했다. 1 주일 단위로 증상이 소실될 때까지 $2.5 \% \mathrm{NaOCl}$ 을 이용한 충 분한 근관세척 및 수산화칼슘제재 근관첩약제인 Calcipex II의 적용을 반복하였고, 모든 증상이 사라진 4주 후 gutta-percha (Sure-Endo, Seoul, Korea)와 ADseal (Meta Biomed, Cheongju, Korea)을 이용하여 근관충전을 시행하였고 근관와동은 Luxacore (DMG, Hamburg, Germany)을 이용하여 충전하였 다.

그 후 주기적인 검사를 통한 치근단 방사선사진 검사 결과 골 의 치유가 서서히 일어나 치근단의 방사선 투과상 병소의 크기 가 점차 감소되는 것을 확인할 수 있었으며, 치료 완료 26개월 후의 방사선검사 결과 치근단 병소의 적절한 치유 상태가 관찰 되었고(Fig. 2), 환자는 무증상이었다.

\section{증례 2}

42세 여자 환자가 반복된 근관치료 후에도 근관을 통한 지속 적인 삼출액 배농으로 인해 발치 또는 치근단절제술을 권유받 고 본원으로 내원하였다. 임상검사 및 방사선검사 결과 \#31은 근관치료 중이었고 환자는 무증상이었으며, 문진을 통해 10여 년 전 하악 전치부 외상 기왕력을 확인할 수 있었다. \#32, \#31, \#41의 치근단 부위에 걸친 커다란 치근단 병소가 관찰되었으며, $\mathrm{CT}$ 검사 결과 하악 전치부 협측 피질골이 파괴된 것과 설측 피 질골이 얇게 남아있는 것을 확인할 수 있었다(Fig. 3). 전기치수 반응 검사 결과 근관치료 중인 \#31 외에, \#32는 양성 반응을 보


Fig. 1. Preoperative radiograph using computed tomography of case 1: coronal view (A), axial view (B), and sagittal view (C). 

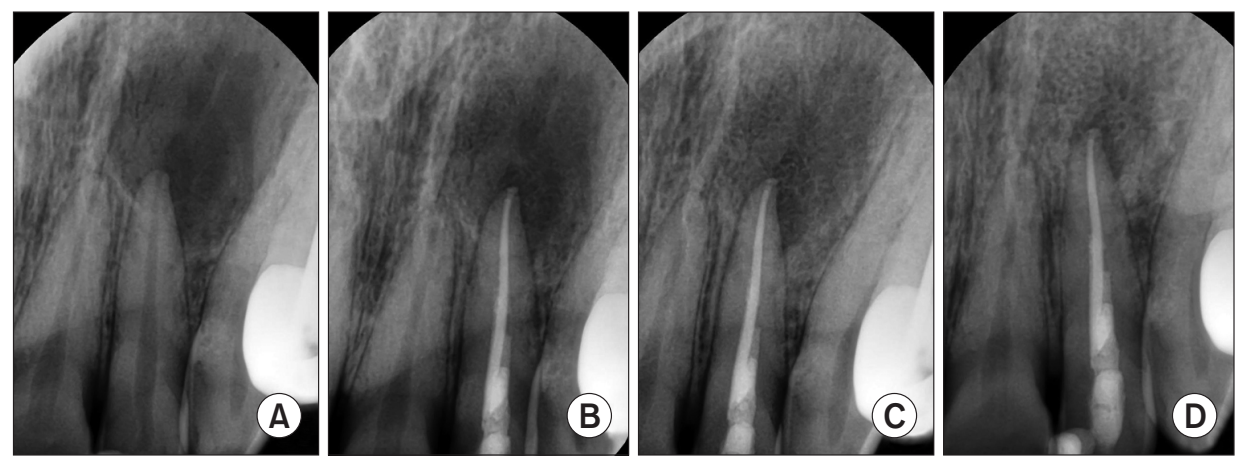

Fig. 2. Radiographic images of case 1. Preoperative radiograph of \#22 and \#23 showing periapical radiolucency (A), radiograph of \#22 immediately after canal filling (B), 6 months followup radiograph (C), 26 months followup radiograph showing reduction in periapical radiolucency (D).


Fig. 3. Preoperative radiograph using computed tomography of case 2: coronal view (A), axial view (B), and sagittal view (C).

였으나 \#41은 음성 반응을 보였다. \#31에 대한 오랜 기간의 근 관치료 후에도 근관을 통한 배농이 지속적으로 일어나는 이유 가 \#41의 치수괴사 때문일 수 있다고 판단하고, \#41을 포함한 \#31, \#41에 대해 근관치료를 시행하기로 결정하였다. 환자에게 비외과적인 근관치료를 시행한 후 치료에 실패할 경우 수술적 인 치료가 필요할 수 있다는 점을 미리 고지하였고 발치나 수술 적인 치료를 피할 수 있는 가능성에 대해 환자는 매우 만족하였 다.

\#31, \#41의 설면에 근관와동을 형성하고 러버댐을 적용한 후 근관장을 측정(\#31: $17.5 \mathrm{~mm}, \# 41: 19 \mathrm{~mm}$ )하였다. 근관성형 각 단계마다 $10 \mathrm{~mL}$ 이상의 $2.5 \% \mathrm{NaOCl}$ 을 이용하여 근관세척 을 충분히 시행하였고, 수산화칼슘제재 근관첩약제를 근관 내 에 적용하고 근관와동을 임시 가봉하였다. 1 주일 단위로 근관세 척을 반복하였고 4회 치료 후 증상이 소실된 것을 확인하고 근 관충전 및 근관와동 충전을 시행하였다.

주기적인 검사 결과 환자는 증상이 없었으며 치료 완료 27 개 월 후 치근단 방사선사진 검사 결과 치근단의 방사선 투과상 병 소가 점차 감소되면서 사라지는 것을 확인할 수 있었다(Fig. 4).

\section{증례 3}

38세 남자 환자가 이전 치과에서 지속적인 치료 후에도 해소 되지 않는 부종 및 \#12 치아의 근관석회화와 관련하여 외과적 인 치료를 권유받고 본원으로 내원하였다. 환자는 부종의 재발 및 불편감을 호소하였고 임상검사 결과 상악 우측 순측 전정에 부종 및 촉진 시 불편감이 확인되었다. 방사선 검사상 \#11은 근 관치료 중이며, \#12는 근관석회화로 인해 근관 입구 $1 / 3$ 지점까 지 근관와동이 형성된 상태였다. CT 검사 결과 \#11 치근단 부 위부터 \#13 치근단 부위에 걸친 커다란 치근단 병소가 관찰되 었고, 상악 우측 전치부 순측 및 구개측 피질골이 얇게 남아있는 것을 확인할 수 있었다(Fig. 5). 전기치수반응 검사 결과 \#13의 치수생활력이 확인되어 \#11 및 \#12에 대한 근관치료를 먼저 시 행하기로 하였다.

\#11 및 \#12에 대해 충분한 $2.5 \% \mathrm{NaOCl}$ 근관세척제 및 수산 화칼슘제재 근관첩약제를 사용한 통상적인 근관치료를 시행하 였고, 순측 부종 및 불편감 감소 확인 후 근관충전을 시행하였 다. 병소의 치유가 일어나지 않을 경우 추가적인 외과적 치료 가 필요할 수 있음을 환자에게 고지하였고 주기적인 검사를 통 

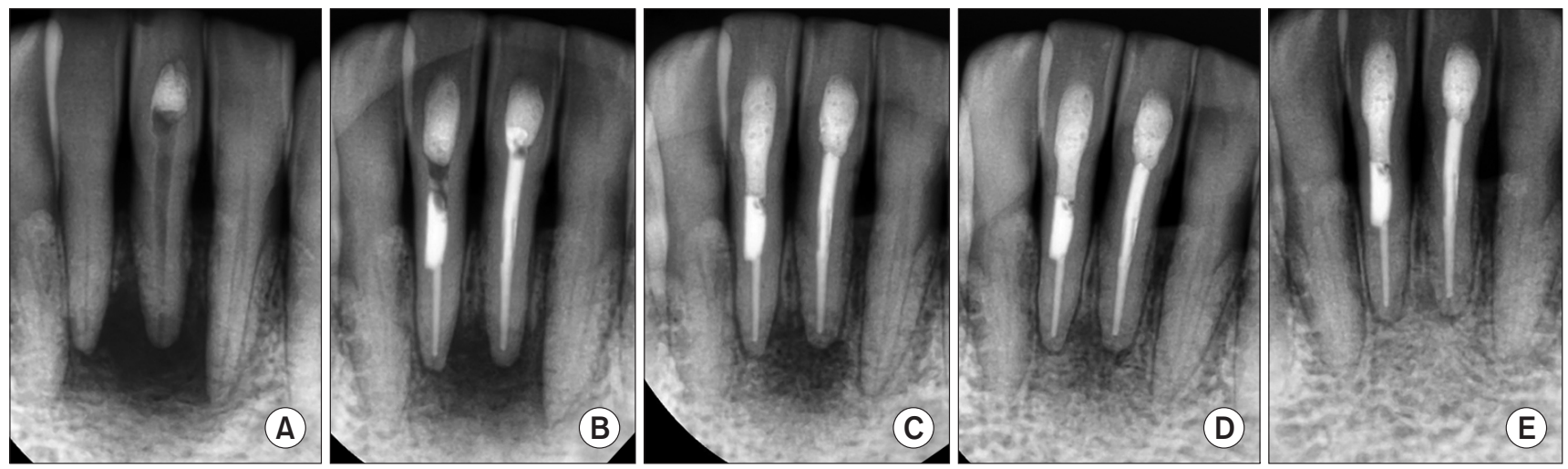

Fig. 4. Radiographic images of case 2. Preoperative radiograph of showing periapical radiolucency in relation to \#31 and \#41 (A), radiograph of \#31 and \#41 immediately after canal filling (B), 6 months follow-up radiograph (C), 12 months follow-up radiograph (D), 27 months follow-up radiograph showing resolving periapical radiolucency $(\mathrm{E})$.
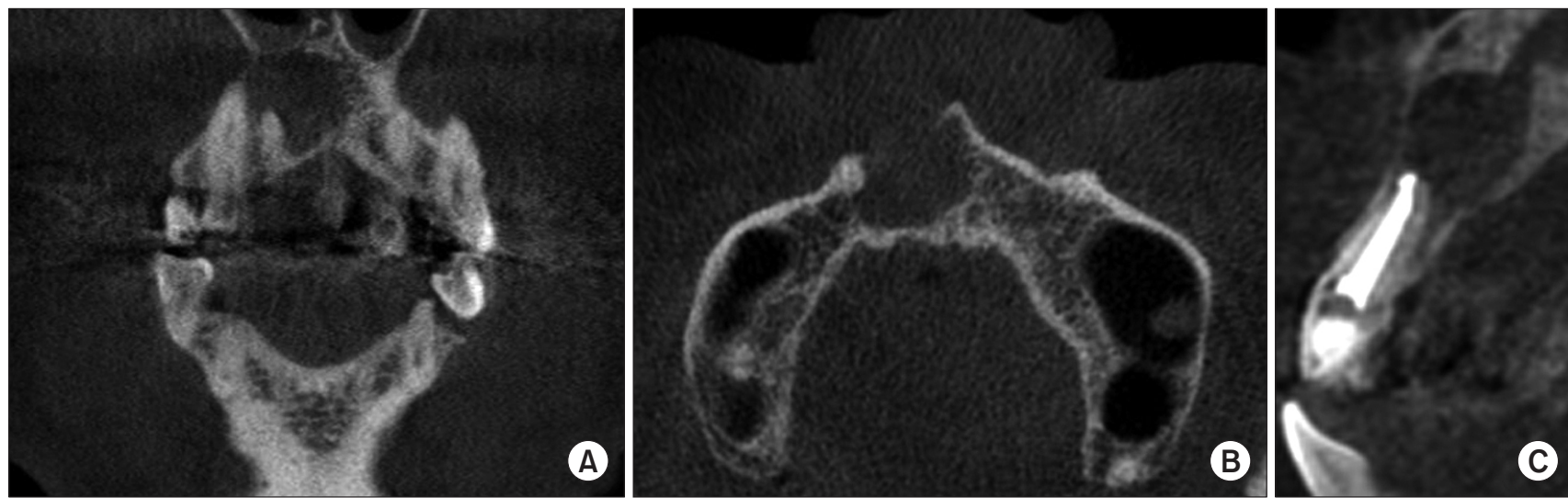

Fig. 5. Preoperative radiograph using computed tomography of case 3: coronal view (A), axial view (B), and sagittal view (C).


(B)
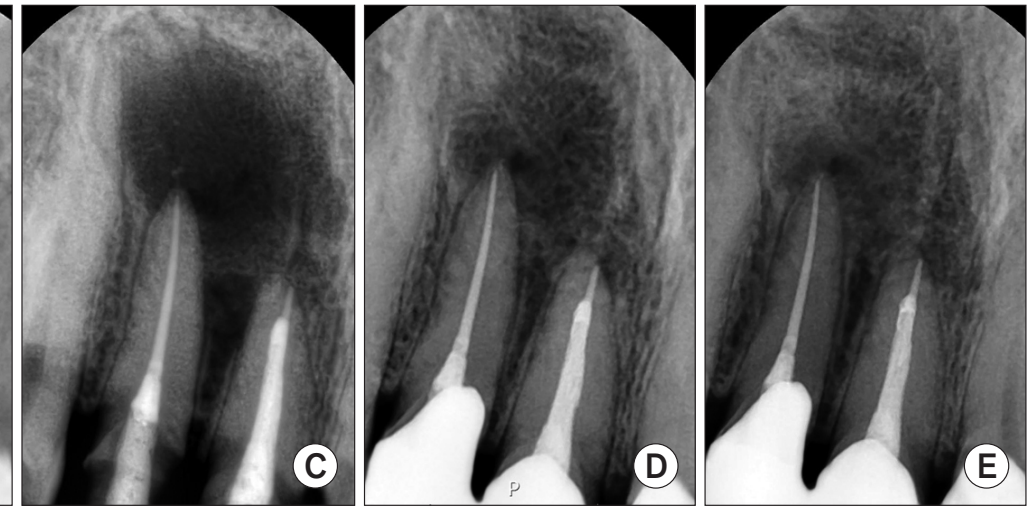

Fig. 6. Radiographic images of case 3. Preoperative radiograph of \#11 and \#12 showing periapical radiolucency (A), radiograph of \#11 and \#12 immediately after canal filling (B), 4 months follow-up radiograph (C), 12 months follow-up radiograph (D), 26 months follow-up radiograph showing reduction in periapical radiolucency $(\mathrm{E})$.

해 증상의 재발 유무와 치유 과정을 확인하기로 하였다. 이전 치 과에서 제작한 임시 치아를 사용하고 있었던 환자의 심미적 요 구에 따라 최종 보철물을 제작하여 임시 합착한 상태로 추적 검
사를 시행하다가 근관 충전 12 개월 후 내원 당시 방사선 사진상 골 치유 양상이 확인되어 최종 보철물 합착을 시행하였다. 근관 충전 26개월 후 환자는 특별한 증상을 호소하지 않았고 방사선 
사진 상에서도 치근단 병소가 치유되는 것을 확인할 수 있었으 며, 외과적인 수술 없이 치유가 진행되고 있다는 점에 대해 환자 는 매우 만족하였다(Fig. 6).

\section{고 찰}

치근단 병소의 형성에 대한 정확한 메커니즘은 완전히 알려 지지는 않았지만, 보통 치수가 괴사되면서 미생물의 번식을 용 이하게 하는 주위 환경이 형성되고 염증 반응을 매개하는 다양 한 독소들이 치근단 조직으로 유출되면서 치근단 병소가 생성 된다고 받아들여지고 있다[12]. 즉, 대부분의 치근단 병소는 근 관 내의 세균 감염에 대한 염증성 반응의 결과물이므로 많은 연 구들에서는 치료를 시행함에 있어 비외과적인 접근이 외과적 접근보다 우선되어야 한다고 보고하고 있다[13-15]. 근관치료 가 적절하게 시행된다면, 근관계에 존재하던 독성 괴사 조직이 중화, 제거될 것이고 이와 같은 과정을 통해 치근단 병소가 해결 될 수 있다[13,14,16].

기계적 근관성형만으로는 측방관(lateral canal)이나 부가적 인 근관(accessory canal) 및 상아세관(dentinal tubules)에 존 재하는 세균과 괴사조직을 모두 제거할 수 없으므로 적절한 기 계적 근관성형 후 근관 내 첩약제의 사용이 중요하다고 알려져 있다[13]. 근관 내 첩약제로 주로 사용되는 수산화칼슘은 높은 알칼리성에 기인한 항염증 작용, 항균 효과, 경조직 침착을 유도 하는 특성을 가져 근관계를 소독시키고 치근단 부위에 광화 조 직을 생성시켜준다[7,15]. Calişkan과 Sen [16]은 근관 내 첩약 제로 수산화칼슘을 적용함으로써 치근단 병소의 $80.8 \%$ 가 완전 하게 치유되었음을 보고한 바 있다. 또한, 근관세척제로 사용한 $\mathrm{NaOCl}$ 역시 감염된 근관의 미생물을 감소시키고 괴사된 조직 을 제거하는 데 도움을 주는 역할을 한다[9].

치근단 병소에 대한 근관치료의 성공 여부는 보통 임상적, 방 사선학적 추적 검사를 통해 평가되며, 치근단 조직의 회복을 평 가하는 데 있어 구내방사선사진을 주로 이용한다[14,17]. 병소 내의 골밀도 변화, 골 소주의 형성, 치조백선의 생성과 같은 방 사선 사진상 징후들은 치유가 일어나고 있다는 것을 의미한다 [18]. 이번 증례보고 결과, 보존적인 근관치료를 시행한 지 약 6-12개월 후부터 치유 양상이 관찰되었으며, 2년 정도 경과하 여 추적관찰을 시행하였을 때 적절한 근관치료 시행만으로도 구내방사선사진 촬영상 치근단 조직의 치유가 성공적으로 일어 난 것을 확인할 수 있었다.

치근단 병소 중 치근낭의 발생빈도는 6\%-55\%, 치근단 치주 염의 발생빈도는 9.3\%-87.1\%, 농양의 경우 발생빈도가 $28.7 \%-$ $70.07 \%$ 인 것으로 알려져 있다[19]. 치근낭 중에서도 낭이 치근 첨과 떨어져 닫혀 있는 형태를 취하는 진성낭의 경우 근관 내
의 자극원의 존재 유무에 영향을 받지 않는 자기 주도적(selfsustaining)인 특성을 가지고 있으므로, 특히 크기가 큰 진성낭 의 경우 통상적인 근관치료로는 치료가 되지 않고 외과적인 접 근을 필요로 할 때가 종종 있다[20]. 또한, 커다란 병소의 경우 병소 자체가 근관 내 세균의 저장고 역할을 하여 일상적인 근 관치료 동안 적용되는 항균제들에 저항할 수 있다는 보고도 있 으며[21], 치성기원의 낭이 성장하는 데 낭 내부의 낭액의 압력 이 기여를 한다는 보고도 있다[22]. 이런 경우 근관치료에 실패 할 가능성이 있으며, 적절한 치료법으로서 낭성 병소의 크기를 줄여주는 데 효과적인 감압술이 추천되기도 한다[23]. 또한, 이 번 증례보고에서처럼 상악 전치부, 하악 전치부에 병소가 확인 될 경우, 각 부위에 호발하는 다른 질환과의 감별진단도 필요하 다. 예를 들어, 상악 전치부에는 비구개관낭(nasopalatine duct cyst)의 상피 잔사로 기원되는 부종, 배농, 동통, 또는 무증상이 며 주변 치아의 생활력에는 보통 영향을 주지 않는 비구개관낭 이 호발하며[24], 하악 전치부에는 처음에는 방사선 투과상 병 소를 보이다가 점차 방사선 투과성 병소 내에 방사선 불투과성 물질이 존재하면서 방사선 불투과성 병소 주변으로 방사선 투 과성대가 둘러싸는 양상을 단계적으로 보이며, 주변 치아의 생 활력에는 영향을 주지 않는 것이 특징인 치근단 백악질 이형성 증(periapical cemental dysplasia)이 호발한다[25]. 이런 병소 들의 경우 근관치료가 아닌 외과적 적출술을 시행해야 하거나 특별한 경우가 아니면 아무런 치료를 필요로 하지 않기 때문에 이에 대한 감별진단 역시 중요하다.

보통, 치근단 병소 중 진성낭의 발생 빈도는 9\% 정도로 알려 져 있으며[20], 외과적 수술을 시행할 경우 주변 치아의 생활력 상실 및 해부학적 구조물의 손상 위험, 반흔 형성이 문제가 되 고, 환자에게 불쾌감을 줄 수 있다. 또한 치근 주위 조직은 치 유에 있어 잠재력을 지니고 있는 풍부한 혈류 공급, 림프 배출 (lymphatic drainage), 다량의 미분화 세포를 가지고 있다[18]. 그러므로 치근 주위 조직에 양호한 치유 환경을 제공해주기 위 해서라도 치근단 병소를 치료하기 위한 첫 번째 치료 방법 선택 은 치근 주위 조직을 외과적으로 제거하기보다는 근관을 통해 미생물 감염원을 제거하여 양호한 치유 환경을 제공하는 쪽으 로 맞춰져야 하며, 적절한 근관치료 후에도 치유되지 않는 치근 단 병소에 한해서 외과적 치료를 시행해야 한다.

이번 증례들은 모두 이전 치과에서 외과적 치료를 계획하고 의뢰된 경우임에도 불구하고 석회화된 근관을 가진 치아에 대 해 적절한 근관치료를 시행하는 것, 병소와 인접한 치아의 이환 여부에 대한 정확한 파악을 통해 이환 치아 모두를 적절히 치료 하는 것 등의 정확한 진단과 적절한 근관치료만으로도 커다란 치근단 병소를 성공적으로 치료할 수 있었다는 것에 의의를 가 진다고 할 수 있다. 커다란 치근단 병소를 치료할 때는 비외과적 
인 접근법이 외과적 수단에 앞서 항상 먼저 시도되어야 하며, 외 과적인 접근법은 비외과적인 근관치료가 실패하였을 때 고려되 어야 한다.

\section{ACKNOWLEDGEMENTS}

This study was supported by a Clinical Research Grant from Pusan National University Hospital (2019).

\section{CONFLICTS OF INTEREST}

The authors declare that they have no competing interests.

\section{ORCID}

\author{
Kyoung-Hwa Jung \\ https://orcid.org/0000-0002-8305-0016 \\ Eun-Young Kwon \\ https://orcid.org/0000-0001-9555-0360 \\ So-Yeun Kim \\ https://orcid.org/0000-0001-6714-8315 \\ Hye-Mi Jeon \\ https://orcid.org/0000-0003-0007-5662 \\ Youn-Kyung Choi \\ https://orcid.org/0000-0003-1491-2986 \\ Sung-Ae Son \\ https://orcid.org/0000-0002-8421-4000 \\ Jeong-Kil Park \\ https://orcid.org/0000-0001-6333-8138
}

\section{REFERENCES}

1. Nair PN. Apical periodontitis: a dynamic encounter between root canal infection and host response. Periodontol 2000 1997;13:121-148. doi: 10.1111/j.1600-0757.1997. tb00098.x.

2. Nair PN. Pathogenesis of apical periodontitis and the causes of endodontic failures. Crit Rev Oral Biol Med 2004;15:348-381. doi: 10.1177/154411130401500604.

3. Ramachandran Nair PN, Pajarola G, Schroeder HE. Types and incidence of human periapical lesions obtained with extracted teeth. Oral Surg Oral Med Oral Pathol Oral Radiol Endod 1996;81:93-102. doi: 10.1016/S10792104(96)80156-9.
4. Simon JH. Incidence of periapical cysts in relation to the root canal. J Endod 1980;6:845-848. doi: 10.1016/S00992399(80)80039-2.

5. Mejia JL, Donado JE, Basrani B. Active nonsurgical decompression of large periapical lesions--3 case reports. J Can Dent Assoc 2004;70:691-694.

6. Torres-Lagares D, Segura-Egea JJ, Rodríguez-Caballero A, Llamas-Carreras JM, Gutiérrez-Pérez JL. Treatment of a large maxillary cyst with marsupialization, decompression, surgical endodontic therapy and enucleation. J Can Dent Assoc 2011;77:b87.

7. Soares J, Santos S, Silveira F, Nunes E. Nonsurgical treatment of extensive cyst-like periapical lesion of endodontic origin. Int Endod J 2006;39:566-575. doi: 10.1111/j.13652591.2006.01109.x.

8. Calişkan MK. Prognosis of large cyst-like periapical lesions following nonsurgical root canal treatment: a clinical review. Int Endod J 2004;37:408-416. doi: 10.1111/j.13652591.2004.00809.x.

9. Öztan MD. Endodontic treatment of teeth associated with a large periapical lesion. Int Endod J 2002;35:73-78. doi: 10.1046/j.1365-2591.2002.00455.x.

10. Rees JS. Conservative management of a large maxillary cyst. Int Endod J 1997;30:64-67. doi: 10.1111/j.13652591.1997.tb01100.x.

11. Murphy WK, Kaugars GE, Collett WK, Dodds RN. Healing of periapical radiolucencies after nonsurgical endodontic therapy. Oral Surg Oral Med Oral Pathol 1991;71:620-624. doi: 10.1016/0030-4220(91)90374-1.

12. al-Kandari AM, al-Quoud OA, Gnanasekhar JD. Healing of large periapical lesions following nonsurgical endodontic therapy: case reports. Quintessence Int 1994;25:115-119.

13. Dandotikar D, Peddi R, Lakhani B, Lata K, Mathur A, Chowdary UK. Nonsurgical management of a periapical cyst: a case report. J Int Oral Health 2013;5:79-84.

14. Sood N, Maheshwari N, Gothi R, Sood N. Treatment of large periapical cyst like lesion: a noninvasive approach: a report of two cases. Int J Clin Pediatr Dent. 2015;8:133137. doi: 10.5005/jp-journals-10005-1299.

15. Santos Soares SM, Brito-Júnior M, de Souza FK, Zastrow EV, Cunha CO, Silveira FF, Nunes E, César CA, Glória JC, Soares JA. Management of cyst-like periapical lesions by orthograde decompression and long-term calcium hydroxide/chlorhexidine intracanal dressing: a case series. J Endod 2016;42:1135-1141. doi: 10.1016/j.joen.2016.04.021.

16. Calişkan MK, Sen BH. Endodontic treatment of teeth with apical periodontitis using calcium hydroxide: a longterm study. Endod Dent Traumatol 1996;12:215-221. doi: 10.1111/j.1600-9657.1996.tb00518.x.

17. Tabassum S, Khan FR. Failure of endodontic treatment: the usual suspects. Eur J Dent 2016;10:144-147. doi: 10.4103/1305-7456.175682.

18. Saatchi M. Healing of large periapical lesion: a non- 
surgical endodontic treatment approach. Aust Endod J 2007;33:136-140. doi: 10.1111/j.1747-4477.2007.00061.x.

19. Bhaskar SN. Oral surgery--oral pathology conference No. 17, Walter Reed Army Medical Center. Periapical lesions-types, incidence, and clinical features. Oral Surg Oral Med Oral Pathol 1966;21:657-671. doi: 10.1016/00304220(66)90044-2.

20. Nair PN, Sjögren U, Schumacher E, Sundqvist G. Radicular cyst affecting a root-filled human tooth: a long-term posttreatment follow-up. Int Endod J 1993;26:225-233.

21. Ricucci D, Siqueira JF Jr. Biofilms and apical periodontitis: study of prevalence and association with clinical and histopathologic findings. J Endod 2010;36:1277-1288. doi: 10.1016/j.joen.2010.04.007.

22. Oka S, Kubota Y, Yamashiro T, Ogata S, Ninomiya T,
Ito $S$, Shirasuna K. Effects of positive pressure in odontogenic keratocysts. J Dent Res 2005;84:913-918. doi: 10.1177/154405910508401008.

23. Anavi Y, Gal G, Miron H, Calderon S, Allon DM. Decompression of odontogenic cystic lesions: clinical longterm study of 73 cases. Oral Surg Oral Med Oral Pathol Oral Radiol Endod 2011;112:164-169. doi: 10.1016/ j.tripleo.2010.09.069.

24. Swanson KS, Kaugars GE, Gunsolley JC. Nasopalatine duct cyst: an analysis of 334 cases. J Oral Maxillofac Surg 1991;49:268-271. doi: 10.1016/0278-2391(91)90217-A.

25. Smith S, Patel K, Hoskinson AE. Periapical cemental dysplasia: a case of misdiagnosis. Br Dent J 1998;185:122-123. doi: 10.1038/sj.bdj.4809747. 